\title{
LEPTIN RESISTANCE AND TYPE 2 DIABETES
}

Leptin is one of adipocyte-secreted hormones. It signals to the brain and other tissues about the status of body energy reserves. Circulating leptin levels are directly proportional to the amount of the body fat. Leptin concentration increases when surfeit and decreases during fasting. Obese patients are hyperleptinemic compared with thin persons and they are tolerant to the central hypothalamic effects of leptin. The reduced sensitivity toward exogenous and endogenous leptin is commonly referred to as leptin resistance. Alterations in the signaling of the long isoform of the leptin receptor play the crucial role in leptin resistance. Surfeit may induce leptin resistance and other metabolic sequelae of obesity. Leptin insensitivity and insulin resistance play a major role in the development of type 2 diabetes. Metformin remains the preferred first-line pharmacologic agent for the treatment of type 2 diabetes. It reduces hepatic glucose production, increases glucose uptake in peripheral tissue and can lead to weight loss. Metformin decreases both insulin and leptin concentration, restores the sensitivity to these hormones. But some studies have shown poor relationship between metformin action and leptin level. And the mechanism of metformin action on leptin resistance remains unclear. Thus, these issues should be studied as well as polymorphisms in genes encoding metformin action.

KEY WORDS: leptine resistance; type 2 diabetes; metformin.

\section{Leptin role in endocrine system}

Adipose tissue is a complex, essential, and highly active metabolic and endocrine organ. It responds to afferent signals from traditional hormone systems and central nervous system but also expresses and secretes factors with important endocrine functions [1].

The discovery of leptin in 1994 has changed the understanding of hormonal regulation of energy homeostasis and the role of adipose tissue from that of a depot storage organ to that of an active endocrine organ producing several bioactive peptides [2].

Leptin, a 167-amino acid peptide [Fig. 1], is one of the adipocyte-secreted hormones [1].

It is also expressed in other tissues, including placenta, mammary gland, testes, ovary, endometrium, stomach, hypothalamus, pituitary, and others [3].

Leptin signals to brain and other tissues about the status of body energy reserves. Thus, that appropriate changes in food intake, energy expenditure, and nutrient partitioning can occur to maintain whole-body energy balance [4].

Corresponding author: Halyna Loi, Department of Pharmacology with Clinical Pharmacolology, I. Horbachevsky Ternopil State Medical University, 1 Maydan Voli, Ternopil, Ukraine, 46001

Phone number: +380 978975239

E-mail: loy@tdmu.edu.ua
Circulating leptin levels are directly proportional to the amount of the body fat [5] and fluctuate with acute changes in caloric intake [6]. Leptin concentration increases when surfeit and decreases during fasting [7].

Circulating leptin crosses blood brain barrier and mediates its action through the Janus kinase (JAK)-signal transducer and activator of transcription (STAT) pathway (JAK-STAT3) [8].

Leptin exerts pleiotropic effects by binding and activating specific leptin receptors in the hypothalamus and other organs, has direct and indirect effects in metabolically active tissues, and regulates some neuroendocrine axes. Several isoforms of the leptin receptor, resulting from alternative splicing, convey biological activity and are involved in mediating leptin's actions in brain and peripheral organs [2].

The long leptin receptor isoform (ObRb) is expressed particularly in hypothalamus, where it regulates energy homeostasis and neuroendocrine function [9]. In ventromedial hypothalamus leptin stimulates expression of anorexigenic brain-derived neurotrophic factor [10]. In addition, leptin influences neurons that directly or indirectly regulate levels of other circulating hormones (e.g. thyroid hormone, sex steroids, and GH) $[9,11]$. ObRb is also expressed in multiple peripheral tissues, including 


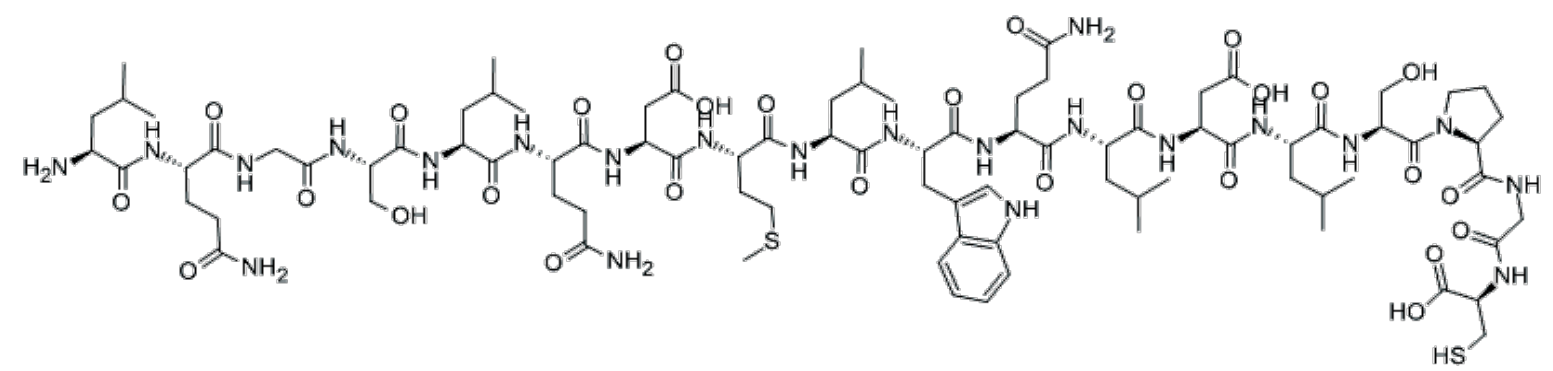

Fig. 1. Leptin structure [81].

pancreatic islets, adipose tissue, skeletal muscle, liver, and immune cells $[12,13]$. In the pancreatic islets, leptin directly inhibits insulin expression and secretion [14]. In liver and white adipose tissue, leptin inhibits lipogenesis and stimulates lipolysis $[12,13]$. Leptin directly promotes fatty acid oxidation in isolated adipocytes and skeletal muscle $[10,15]$ and decreases lipid levels in isolated livers [16].

Leptin takes part in the regulation of energy homeostasis, insulin action and lipid metabolism [1] by improving insulin sensitivity and reducing intracellular lipids [17-19].

The ability of leptin to inhibit feeding is related to activation of PI3 kinase in the hypothalamus. Blockade of PI3 kinase activity prevents the anorectic action of leptin [20].

Congenital leptin deficiency is associated with hyperphagia, impaired thermogenesis, insulin resistance, hyperlipidemia, and central hypogonadism, which can be reversed by leptin treatment $[20,21]$.

Women have higher leptin concentrations than men. But after menopause a significant reduction in the amount of circulating leptin occurs [22]. Such sexual differences can be explained by the difference in fat mass, body fat distribution, and sex hormones. Leptin level is also independent of body mass index. Subcutaneous fat expresses more leptin mRNA than omental (visceral) fat, and this may partially contribute to increased leptin levels in women compared with men [23].

Deficient leptin signaling results in hyperphagia and decreased energy expenditure [24]. The result is not only an increasing degree of obesity associated with increased lipid storage in muscle, liver, and other tissues but also dysfunction of several neuroendocrine axes, including the reproductive, thyroid, and adrenal axes, as well as abnormal function of the immune and autonomic system (i.e. thermoregulation, energy expenditure, and others) $[17,24]$.

Normally leptin reduces along with insulin during fasting and mediates the suppression of thyroid hormone, growth hormone and reproductive hormones. Leptin causes stimulation of appetite and inhibition of sympathetic nerve activity $[25,26]$.

Chronic weight loss in females and obese patients on dietary restriction decreases leptin, resulting in suppression of reproductive hormones, disruption of menstrual cycles, and energy use by muscle $[27,28]$.

Leptin may control glucose homeostasis independently of its effects on adiposity [29]. It regulates glycaemia via the CNS, but it may also directly regulate the physiology of pancreatic $\beta$-cells $[30,31]$ and peripheral insulin-sensitive tissues [32]. It was also proved that leptin acting through LRb regulates insulin receptor substrate-1 and 2, mitogen-activated protein kinase, extracellular signal-regulated kinase, Akt, and PI3 kinase, raising the possibility of interaction between leptin and insulin [33]. Antidiabetic properties of leptin as a suppressor of glucagon are shown in some literature [34-36].

Leptin also limits accumulation of triglycerides in liver and skeletal muscle through a combination of direct activation of AMPK and indirect actions mediated through central neural pathways, thereby improving insulin sensitivity [37]. Attenuation of leptin sensitivity in brain leads to excess triglyceride accumulation in adipose tissue, as well as muscle, liver, and pancreas, resulting in impaired insulin sensitivity and secretion [38].

Although obese subjects are hyperleptinemic compared with thin persons [39], they appear either to be tolerant or resistant to the central hypothalamic effects of leptin. The reduced sensitivity toward exogenous and endogenous leptin is commonly referred to as leptin resistance [40]. However, leptin is not widely used in the clinical field because obesity is accompanied by increased serum leptin and responds poorly to the pharmacological administration of exogenous leptin, which ordinarily potently promotes fat mass loss and body weight reduction in thin subjects $[41,42]$. 
Alterations in the signaling of the long isoform of the leptin receptor, especially in the hypothalamic arcuate nucleus, seem to play a crucial role in leptin resistance. Additional mechanisms that were proposed to induce resistance toward the effects of leptin include alterations in the transport of leptin across the blood-brain barrier. The protein tyrosine phosphatase $1 \mathrm{~B}$ is another potential mechanism that was proposed to interfere with leptin signaling by inhibiting signaling of the long isoform of the leptin receptor $[24,43]$.

Leptin insensitivity and insulin resistance play a major role in the development of type 2 diabetes [44]. It can be explained by high levels of insulin and leptin as well as with hyperphagia in patients with obesity [45].

Leptin resistance as a development factor of obesity and type 2 diabetes

The WHO has declared obesity as the largest global chronic health problem in adults, and it is considered the $5^{\text {th }}$ leading risk for life globally [46]. Obesity is a 'gateway' for diabetes [47].

Worldwide, 415 million people have diabetes, and this number will reach 642 million by 2040 [48]. Type 2 diabetes accounts for $90-95 \%$ of all diabetes.

This form encompasses individuals who have relative (rather than absolute) insulin deficiency and have peripheral insulin resistance [49]. Nearly $90 \%$ of individuals with type 2 diabetes are either overweight or obese [50]. Excess weight itself causes some degree of insulin resistance. Patients with type 2 diabetes may have insulin levels that appear normal or increased; the increased blood glucose levels in these patients would be expected to result in even higher insulin values and to have their b-cell function in norm. Thus, insulin secretion is defective in these patients and insufficient to compensate for insulin resistance [49].

Leptin resistance was introduced in an apparent analogy with that of insulin resistance to explain why hyperleptinemia associated with obesity fails to correct the defect in energy balance and feeding behaviour [51]. In obesity, the transport of leptin across the blood brain barrier is decreased and levels of suppressors of cytokine signaling-3 (SOCS-3), an inhibitor of leptin signaling is increased in hypothalamus, which leads to leptin resistance [52]. Therefore, the concept of 'leptin resistance' has been challenged recently by an alternate concept of 'hypothalamic leptin insufficiency' [53].

It is assumed that leptin resistance contributes to hyperphagia $[54,55]$. It is also possible that surfeit may induce leptin resistance and other metabolic sequelae of obesity [45]. This rapid adaptation to increased energy availability may be designed to curtail the leptin system to facilitate storage of nutrients into lipid stores $[54,56]$. This may be accomplished by restraining leptin biosynthesis [57-59] and/or by inducing leptin resistance $[54,56]$. These mechanisms would be particularly well developed in individuals predisposed to weight gain and diabetes $[54,60]$. Consistent with the 'thrifty genotype' hypothesis, this sequence of events would be tightly coupled to the onset of insulin resistance $[45,54]$.

Inadequate early increase in leptin secretion and biosynthesis (Table 1 ) in response to overeating may also play a role in the development of obesity and glucose intolerance [61].

Table 1. The scheme of metabolic disorders in the human body initiated by leptin resistance (based on the Fig. 2 by Kalra S.P., 2008)

Diminished leptin transport across blood-brain barrier

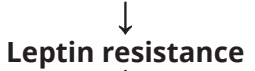

$\downarrow$

Hypothalamic leptin insufficiency with

defections in hypothalamic regulation of energy homeostasis

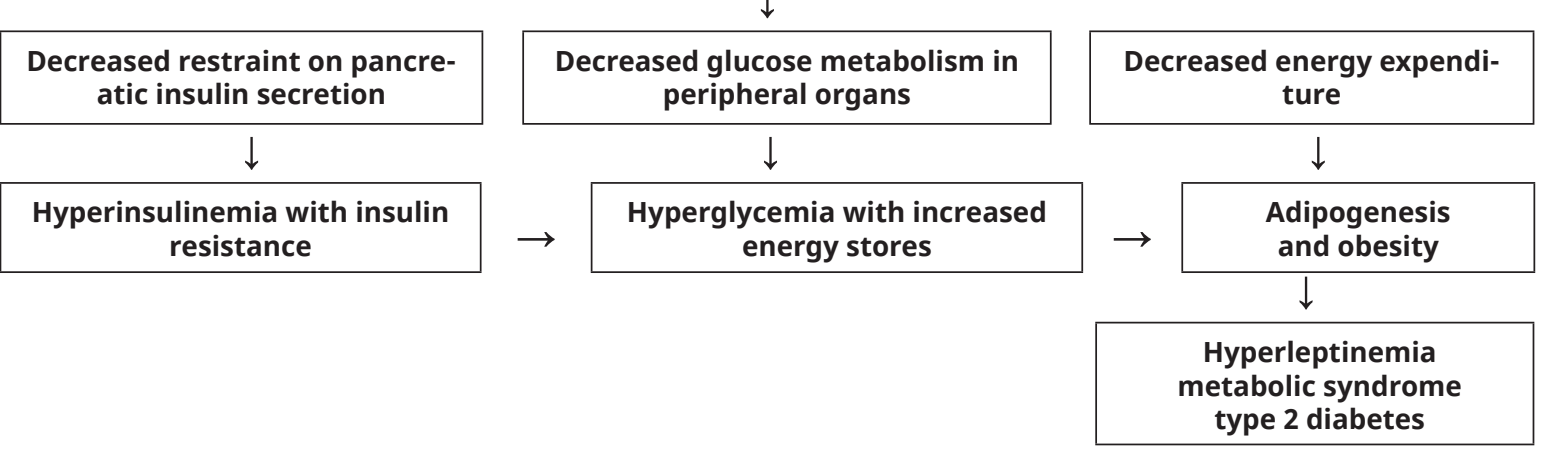




\section{Metformin action in patients with leptin resistance}

Metformin remains the preferred first-line pharmacologic agent for the treatment of type 2 diabetes [62]. The use of metformin as a firstline therapy was supported by the findings of a large meta-analysis with selection of secondline therapies based on patient-specific considerations [63].

Metformin acts mainly by reducing hepatic glucose production via inhibition of gluconeogenesis $[64,65]$ and increases glucose uptake in peripheral tissue [65]. Metformin is associated with a low risk of hypoglycemia and is weight neutral or can lead to weight loss [66].

Moreover, metformin decreases leptin concentration in morbidly obese subjects $[67,68]$ and in normal-weight healthy men [69]. Although leptin concentration is closely related to body fat mass, the leptin-reducing effect of metformin cannot be fully explained by body weight reduction because metformin reduces leptin level even without changing body weight in normal-weight healthy men [69].

It was proved that weight loss achieved by metformin was correlated with pre-treatment plasma leptin levels. This effect of metformin was paralleled by a stimulation of the expression of the leptin receptor gene (ObRb) in the arcuate nucleus. Thus, identifying the hypothalamic ObRb as a gene was modulated after metformin treatment [70].

It has been recently reported that metformin targets the AMP-activated protein kinase (AMPK), which is also activated by leptin [71-73].

Several researches have been performed to analyse the molecular mechanism behind the effect of metformin on leptin levels. An invitro study reports that metformin inhibits leptin secretion by inhibiting MAPK signaling pathway in adipocytes [74].

The other studies has proved that metformin restores leptin sensitivity in obese rats with leptin resistance and metformin treatment increases cerebrospinal fluid leptin concentrations in both standard chow and high fat-fed obese rats compared with the untreated rats. The authors have also reported that metformin increases hypothalamic POMC (an anorexigenic peptide) expression by leptin treatment in high fat-fed obese rats, whereas this is not observed in untreated high fat-fed obese rats [75].
As the effect of leptin is associated with the activation of POMC, failure to activate POMC expression by leptin is an evidence of leptin resistance [76].

Distinct reduction in serum leptin level was observed in non-obese healthy individual on metformin, without any reduction in body weight [77].

But some studies have shown poor relationship between metformin action and leptin level $[78,79]$.

Although many researches have been conducted, the mechanism of metformin action on leptin resistance remains unclear. Moreover, similar investigations have contrary outcomes. Therefore, this issue requires further research.

\section{Conclusions}

Leptin, the adipocyte-secreted hormone, has direct and indirect effects on metabolically active tissues, and regulates several neuroendocrine axes. It takes part in the regulation of energy homeostasis, insulin action and lipid metabolism, and signals primarily on the status of the body energy reserves in fat to brain and other tissues. Circulating leptin levels are directly proportional to the amount of body fat. Leptin concentration are increased in obesity and decreased during fasting. In obesity, the transport of leptin across the blood brain barrier is diminished, which leads to leptin resistance. Leptin insensitivity and insulin resistance play a major role in the development of type 2 diabetes.

Metformin decreases both insulin and leptin concentration, restores the sensitivity to these hormones.

But the mechanism of metformin action on leptin resistance remains unclear. The leptinreducing effect of metformin cannot be fully explained only by body weight reduction. Furthermore, some studies have proved poor relationship between metformin action and leptin level. All these aspects require an in-depth research.

Considering the topical matter of exploring metformin action due to polymorphisms in genes encoding drug receptors, transporters, and metabolizing enzymes [80], the study of the relationship between genetic variants in solute carrier transporters and changes in leptin levels under metformin therapy would be reasonable. 


\section{References}

1. Kershaw E, Flier J. Adipose tissue as an endocrine organ. The Journal of Clinical Endocrinology \& Metabolism. 2004;89(6):2548-2556.

2. Bluher S, Mantzoros C. Leptin in humans: lessons from translational research. The American journal of clinical nutrition. 2009;89(3):991-997.

3. Leibel RL. Molecular physiology of weight regulation in mice and humans. International Journal of Obesity. 2008;32:98-108.

4. De Luis DA, Castrillon JL Perez, Duenas A. Leptin and obesity. Minerva medical J. 2009;100(3): 229-236.

5. Considine R. Serum immunoreactive-leptin concentrations in normal-weight and obese humans. New England Journal of Medicine. 1996;334(5):292-295.

6 . Unger R. Lipotoxic diseases. Annual review of medicine. 2002;53(1):319-336.

7. Boden G, Chen X, Mozzoli M, Ryan I. Effect of fasting on serum leptin in normal human subjects. The Journal of Clinical Endocrinology \& Metabolism. 1996;81(9):3419-23.

8. Houseknecht KL, Baile CA, Matteri RL, Spurlock ME. The biology of leptin: a review. Journal of Animal Science. 1998;76(5):1405-20.

9. Zhang Y, Scarpace PJ. The role of leptin in leptin resistance and obesity. Physiology \& behavior. 2006;88(3):249-56.

10. Prieur $X$, Tung YL, Griffin JL, Farooqi IS, O'Rahilly S, Coll AP. Leptin regulates peripheral lipid metabolism primarily through central effects on food intake. Endocrinology. 2008;149(11):5432-9.

11. Cohen MM. Role of leptin in regulating appetite, neuroendocrine function, and bone remodeling. American Journal of Medical Genetics. Part A. $2006 ; 140(5): 515-24$.

12. Mencarelli A, Distrutti E, Renga B, D'Amore C, Cipriani S, Palladino G, Donini A, Ricci P, Fiorucci S. Probiotics modulate intestinal expression of nuclear receptor and provide counter-regulatory signals to inflammation-driven adipose tissue activation. PLoS One. 2011;6(7):229-78.

13. Lee $Y, Y u X$, Gonzales F, Mangelsdorf DJ, Wang MY, Richardson C, Witters LA, Unger RH. PPARa is necessary for the lipopenic action of hyperleptinemia on white adipose and liver tissue. Proceedings of the National Academy of Sciences. 2002;99(18): 11848-53.

14. Seufert]. Leptin effects on pancreatic $\beta$-cell gene expression and function. Diabetes. 2004;53:152-8.

15. Muhlhausler BS, Morrison JL, McMillen IC. Rosiglitazone increases the expression of peroxisome proliferator-activated receptor-y target genes in adipose tissue, liver, and skeletal muscle in the sheep fetus in late gestation. Endocrinology. 2009;150(9): 4287-94.

16. Gallardo N, Bonzon-Kulichenko E, FernandezAgullo T, Molto E, Gomez-Alonso S, Blanco P, Carrascosa JM, Ros M, Andres A. Tissue-specific effects of central leptin on the expression of genes involved in lipid metabolism in liver and white adipose tissue. Endocrinology. 2007;148(12):5604-10.
17. Caprio M, Fabbrini E, Isidori AM, Aversa A, Fabbri A. Leptin in reproduction. Trends in Endocrinology \& Metabolism. 2001;12(2):65-72.

18. Lee JH, Chan JL, Sourlas E, Raptopoulos V, Mantzoros CS. Recombinant methionyl human leptin therapy in replacement doses improves insulin resistance and metabolic profile in patients with lipoatrophy and metabolic syndrome induced by the highly active antiretroviral therapy. The Journal of Clinical Endocrinology \& Metabolism. 2006;91(7): 2605-11.

19. Ronti T, Lupattelli G, Mannarino E. The endocrine function of adipose tissue: an update. Clinical endocrinology. 2006;64(4):355-65.

20. Flier JS. Obesity wars: molecular progress confronts an expanding epidemic. Cell. 2004;116(2): 337-50.

21. Zhang $Y$, Proenca R, Maffei M, Barone $M$, Leopold L, Friedman JM. Positional cloning of the mouse obese gene and its human homologue. Nature. 1994;372(6505):425.

22. Muller TD, Focker M, Holtkamp K, HerpertzDahlmann B, Hebebrand J. Leptin-mediated neuroendocrine alterations in anorexia nervosa: somatic and behavioral implications. Child and adolescent psychiatric clinics of North America. 2009;18(1):117-29.

23. Leshan RL, Björnholm M, Münzberg $H$, Myers MG. Leptin receptor signaling and action in the central nervous system. Obesity. 2006;14(8):208-12.

24. Myers MG, Cowley MA, Munzberg H. Mechanisms of leptin action and leptin resistance. Annu Rev Physiol. 2008;70:537-56.

25. Ahima RS, Prabakaran D, Mantzoros C, Qu D. Role of leptin in the neuroendocrine response to fasting. Nature. 1996;382(6588):250.

26. Lord GM, Matarese G, Howard JK, Baker RJ, Bloom SR, Lechler RI. Leptin modulates the T-cell immune response and reverses starvation-induced immunosuppression. Nature. 1998;394(6696):897901.

27. Chan JL, Heist K, DePaoli AM, Veldhuis JD, Mantzoros CS. The role of falling leptin levels in the neuroendocrine and metabolic adaptation to shortterm starvation in healthy men. The Journal of clinical investigation. 2003;111(9):1409-21.

28. Rosenbaum M, Goldsmith R, Bloomfield D, Magnano A, Weimer L, Heymsfield S, Gallagher D, Mayer L, Murphy E, Leibel RL. Low-dose leptin reverses skeletal muscle, autonomic, and neuroendocrine adaptations to maintenance of reduced weight. The Journal of clinical investigation. 2005; 115(12):3579-86.

29. Moon HS, Dalamaga M, Kim SY, Polyzos SA, Hamnvik OP, Magkos F, Paruthi J, Mantzoros CS. Leptin's role in lipodystrophic and nonlipodystrophic insulin-resistant and diabetic individuals. Endocrine reviews. 2013;34(3):377-412.

30. Gray SL, Donald C, Jetha A, Covey SD, Kieffer TJ. Hyperinsulinemia precedes insulin resistance in mice lacking pancreatic $\beta$-cell leptin signaling. Endocrinology. 2010;151(9):4178-86. 
31. Maedler K, Schulthess FT, Bielman C, Berney T, Bonny C, Prentki M, Donath MY, Roduit R. Glucose and leptin induce apoptosis in human $\beta$-cells and impair glucose-stimulated insulin secretion through activation of c-Jun $\mathrm{N}$-terminal kinases. The FASEB Journal. 2008;22(6):1905-13.

32. Miras M, Ochetti M, Martín S, Silvano L, Sobrero G, Castro L, Onassis M, de Talamoni NT, Perez A, Picotto G, de Barboza GD. Serum levels of adiponectin and leptin in children born small for gestational age: relation to insulin sensitivity parameters. Journal of Pediatric Endocrinology and Metabolism. 2010;23(5):463-71.

33. Niswender KD, Baskin DG, Schwartz MW. Insulin and its evolving partnership with leptin in the hypothalamic control of energy homeostasis. Trends in Endocrinology \& Metabolism. 2004 Oct 31;15(8): 362-9.

34. Wang MY, Chen L, Clark GO, Lee Y, Stevens RD, Ilkayeva OR, Wenner BR, Bain JR, Charron MJ, Newgard CB, Unger RH. Leptin therapy in insulindeficient type I diabetes. Proceedings of the National Academy of Sciences. 2010;107(11):4813-9.

35. Unger RH, Orci L. Paracrinology of islets and the paracrinopathy of diabetes. Proceedings of the National Academy of Sciences. $2010 ; 107(37): 16009-$ 12.

36. Yu X, Park BH, Wang MY, Wang ZV, Unger RH. Making insulin-deficient type 1 diabetic rodents thrive without insulin. Proceedings of the National Academy of Sciences. 2008;105(37):14070-5.

37. Kondo H, Shimomura I, Matsukawa Y, Kumada M, Takahashi M, Matsuda M, Ouchi N, Kihara S, Kawamoto T, Sumitsuji S, Funahashi T. Association of adiponectin mutation with type 2 diabetes. Diabetes. 2002;51(7):2325-8.

38. Saito K, Takashi TO, Madoka YO, NAKANO $Y$, Nam-Ho CM, TOMITA M. Regulation of gelatinbinding protein 28 (GBP28) gene expression by C/ EBP. Biological and Pharmaceutical Bulletin. 1999; 22(11):1158-62.

39. Kiess W, Petzold S, Topfer M, Garten A, Blüher S, Kapellen T, Körner A, Kratzsch J. Adipocytes and adipose tissue. Best Practice \& Research Clinical Endocrinology \& Metabolism. 2008;22(1):135-53.

40. Brennan AM, Mantzoros CS. Drug Insight: the role of leptin in human physiology and pathophysiology - emerging clinical applications. Nature Reviews Endocrinology. 2006;2(6):318-27.

41. Widdowson PS, Upton R, Buckingham R, Arch J, Williams G. Inhibition of food response to intracerebroventricular injection of leptin is attenuated in rats with diet-induced obesity. Diabetes. 1997;46(11):1782-5.

42. Shek EW, Scarpace PJ. Resistance to the anorexic and thermogenic effects of centrally administrated leptin in obese aged rats. Regulatory peptides. 2000;92(1):65-71.

43. Munzberg H. Differential leptin access into the brain - a hierarchical organization of hypothalamic leptin target sites. Physiology \& behavior. 2008; 94(5):664-9.
44. Saad M, Pettitt D, Mott D, Knowler W, Nelson R, Bennett P. Sequential changes in serum insulin concentration during development of noninsulin-dependent diabetes. The Lancet. 1989; 333(8651):1356-9.

45. Wang J, Obici S, Morgan K, Barzilai N, Feng Z, Rossetti L. Overfeeding rapidly induces leptin and insulin resistance. Diabetes. 2001;50(12):2786-91.

46. World Health Organization: Fact Sheet No.311.2012. www.who.int/mediacentre/factsheets/ fs311/en/. Accessed May 2012.

47. Toplak H, Woodward E, Yumuk V, Oppert JM, Halford JC, Fruhbeck G. 2014 EASO Position Statement on the Use of Anti-Obesity Drugs. Obesity facts. 2015;8(3):166-74.

48. International Diabetes Federation. IDF Diabetes Atlas. 7th ed. Brussels: International Diabetes Federation; 2015.

49. American Diabetes Association. Classification and Diagnosis of Diabetes. Diabetes Care Jan 2017; 40 (Supplement 1):11-24.

50. Kumanyika S, Jeffery RW, Morabia A, Ritenbaugh C, Antipatis VJ. Obesity prevention: the case for action. International journal of obesity. 2002; 26(3):425.

51. Upadhyaya P, Rehan HS, Seth V. Serum leptin changes with metformin treatment in polycystic ovarian syndrome: correlation with ovulation, insulin and testosterone levels. EXCLI journal. 2011;10-9.

52. Farooqi IS, Matarese G, Lord GM, Keogh JM, Lawrence E, Agwu C, Sanna V, Jebb SA, Perna F, Fontana S, Lechler RI. Beneficial effects of leptin on obesity, T cell hyporesponsiveness, and neuroendocrine/metabolic dysfunction of human congenital leptin deficiency. The Journal of clinical investigation. 2002;110(8):1093-103.

53. Iwaki M, Matsuda M, Maeda N, Funahashi T, Matsuzawa Y, Makishima M, Shimomura I. Induction of adiponectin, a fat-derived antidiabetic and antiatherogenic factor by nuclear receptors. Diabetes. 2003;52(7):1655-63.

54. Caro JF, Sinha MK, Kolaczynski JW, Zhang PL, Considine RV. Leptin: the tale of an obesity gene. Diabetes. 1996;45(11):1455-63.

55. Igel M, Becker W, Herberg L, Joost HG. Hyperleptinemia, Leptin Resistance, and Polymorphic Leptin Receptor in the New Zealand Obese Mouse 1. Endocrinology. 1997;138(10):4234-9.

56. Frederich RC, Hamann A, Anderson S, Löllmann B, Lowell BB, Flier JS. Leptin levels reflect body lipid content in mice: evidence for diet-induced resistance to leptin action. Nature medicine. 1995; 1(12):1311-4.

57. Wang J, Liu R, Liu L, Chowdhury R, Barzilai N, Tan J, Rossetti L. The effect of leptin on Lep expression is tissue-specific and nutritionally regulated. Nature medicine. 1999;5(8):895-9.

58. Friedman JM, Halaas JL. Leptin and the regulation of body weight in mammals. Nature. 1998; 395(6704):763-70.

59. Surwit RS, Petro AE, Parekh P, Collins S. Low plasma leptin in response to dietary fat in diabe- 
tes and obesity-prone mice. Diabetes. 1997;46(9): 1516-20.

60. Flier, Jeffrey S. Leptin expression and action: new experimental paradigms. Proceedings of the National Academy of Sciences. 1997; 94(9):4242-4245.

61. Ravussin E, Pratley RE, Maffei M, Wang $H_{\text {, }}$ Friedman JM, Bennett PH, Bogardus C. Relatively low plasma leptin concentrations precede weight gain in Pima Indians. Nature medicine. 1997;3(2):238-40.

62. American Diabetes Association. Standards of Medical Care in Diabetes-2017 Abridged for Primary Care Providers. Clinical Diabetes. 2017;35(1):5-26.

63. Palmer SC, Mavridis D, Nicolucci A, Johnson DW, Tonelli M, Craig JC, Maggo J, Gray V, De Berardis G, Ruospo M, Natale P. Comparison of clinical outcomes and adverse events associated with glucose-lowering drugs in patients with type 2 diabetes: a meta-analysis. Jama. 2016;316(3):313-24.

64. Hundal RS, Krssak M, Dufour S, Laurent $D$, Lebon V, Chandramouli V, Inzucchi SE, Schumann WC, Petersen KF, Landau BR, Shulman GI. Mechanism by which metformin reduces glucose production in type 2 diabetes. Diabetes. 2000;49(12):2063-9.

65. Basu R, Shah P, Basu A, Norby B, Dicke B, Chandramouli V, Cohen O, Landau BR, Rizza RA. Comparison of the effects of pioglitazone and metformin on hepatic and extra-hepatic insulin action in people with type 2 diabetes. Diabetes. 2008; 57(1):24-31.

66. Inzucchi SE, Bergenstal RM, Buse JB, Diamant M, Ferrannini E, Nauck M, Peters AL, Tsapas A, Wender R, Matthews DR. Management of hyperglycemia in type 2 diabetes, 2015: a patient-centered approach: update to a position statement of the American Diabetes Association and the European Association for the Study of Diabetes. Diabetes care. 2015;38(1):140-9.

67. Kay JP, Alemzadeh R, Langley G, D'angelo L, Smith $P$, Holshouser S. Beneficial effects of metformin in normoglycemic morbidly obese adolescents. Metabolism. 2001;50(12):1457-61.

68. Glueck CJ, Fontaine RN, Wang P, Subbiah MT, Weber K, Illig E, Streicher P, Sieve-Smith L, Tracy TM, Lang JE, McCullough P. Metformin reduces weight, centripetal obesity, insulin, leptin, and low-density lipoprotein cholesterol in nondiabetic, morbidly obese subjects with body mass index greater than 30. Metabolism. 2001;50(7):856-61.

69. Fruehwald-Schultes B, Oltmanns KM, Toschek B, Sopke S, Kern W, Born J, Fehm HL, Peters A. Short-term treatment with metformin decreases serum leptin concentration without affecting body weight and body fat content in normal-weight healthy men. Metabolism. 2002;51(4):531-6.

70. Aubert G, Mansuy V, Voirol MJ, Pellerin L,
Pralong FP. The anorexigenic effects of metformin involve increases in hypothalamic leptin receptor expression. Metabolism. 2011;60(3):327-34.

71. Zhou G, Myers R, Li Y, Chen Y, Shen X, FenykMelody J, Wu M, Ventre J, Doebber T, Fujii N, Musi N. Role of AMP-activated protein kinase in mechanism of metformin action. The Journal of clinical investigation. 2001;108(8):1167-74.

72. Hawley SA, Gadalla AE, Olsen GS, Hardie DG. The antidiabetic drug metformin activates the AMPactivated protein kinase cascade via an adenine nucleotide-independent mechanism. Diabetes. 2002;51(8):2420-5.

73. Minokoshi Y, Kim YB, Peroni OD, Fryer LG, Müller C, Carling D, Kahn BB. Leptin stimulates fattyacid oxidation by activating AMP-activated protein kinase. Nature. 2002;415(6869):339-43.

74. Klein J, Westphal S, Kraus D, Meier B, Perwitz N, Ott $\mathrm{V}$, Fasshauer $\mathrm{M}$, Klein $\mathrm{HH}$. Metformin inhibits leptin secretion via a mitogen-activated protein kinase signalling pathway in brown adipocytes. Journal of endocrinology. 2004;183(2):299-307.

75. Kim YW, Kim JY, Park YH, Park SY, Won KC, Choi KH, Huh JY, Moon KH. Metformin restores leptin sensitivity in high-fat-fed obese rats with leptin resistance. Diabetes. 2006;55(3):716-24.

76. Kim YW, Choi DW, Park YH, Huh JY, Won KC, Choi KH, Park SY, Kim JY, Lee SK. Leptin-like effects of MTII are augmented in MSG-obese rats. Regulatory peptides. 2005;127(1):63-70.

77. Fruehwald-Schultes B, Oltmanns KM, Toschek B, Sopke S, Kern W, Born J, Fehm HL, Peters A. Shortterm treatment with metformin decreases serum leptin concentration without affecting body weight and body fat content in normal-weight healthy men. Metabolism. 2002;51(4):531-6.

78. Guler S, Gürsoy G, Serter R, Aral Y. Leptin concentrations are related to glycaemic control, but do not change with short-term oral antidiabetic therapy in female patients with type 2 diabetes mellitus. Diabetes, Obesity and Metabolism. 2000; 2(5):313-6.

79. Adamia N, Virsaladze D, Charkviani N, Skhirtladze M, Khutsishvili M. Effect of metformin therapy on plasma adiponectin and leptin levels in obese and insulin resistant postmenopausal females with type 2 diabetes. Georgian Med News. 2007; 145:52.

80. Pasechko NV, Oleshchuk OM, Loi GY. Pharmacogenetic Aspects of Metformin Action in Patients with Type 2 Diabetes Mellitus. International Journal of Endocrinology. 2016;8(80):66-72.

81. Leptin (150-167) (Human). 2016. http://www. chemicalbook.com/ProductChemicalPropertiesCB3304602_EN.htm. Accessed 2016. 